\title{
Global Tourism Management. Mass, Experience and Sensations Tourism
}

\author{
Silvio M. Brondoni*
}

\begin{abstract}
The globalisation of tourism is the result of a more general trend of growing economic globalisation and technological advancements in communications and transportation. Over the years, travel and tourism have transformed into the world's largest economic sector, with enormous ramifications. Globalisation has determined new landscapes of tourism growth with the emergence of a new tourist profile. This new panorama imposes tourism management with a global approach and corporations structured on networks where management faces two specific supply and demand drivers. Global demand drivers require developing different segments of global mass tourism while the offer drivers relate to corporate transfer pricing and sustainability policies, often-opposing forces, but always correlated with short- and long-term profit.
\end{abstract}

Keywords: Global Tourism; Management; Global Markets; Transfer Pricing in Tourism Management; Sustainability in Tourism Management; Mass Tourism; Experience Tourism; Sensations Tourism

\section{Tourism and Globalisation}

The globalisation of tourism is the result of a more general trend of growing economic globalisation and technological advancements in communications and transportation. For these reasons, tourism globalization can be defined as a 'megatrend' with different dimensions and consequences (Adejuwon, 1996).

In a specific sense, tourism globalisation entails some different basic elements. The first element is the geographic aspect. Globalisation involves intraregional and interregional travel, and extending tourism on a worldwide scale. Global tourism can thus be seen in terms converging world tastes, product preferences and lifestyles. The second basic element is the existence of similar tourism practices around the world including distribution systems, marketing practices, product development, and so forth (Vanhove, 1996; Heath, 2001).

The growing importance of tourism globalisation in recent decades is a consequence of several factors: the increase in populations with higher incomes and leisure-time, the lower cost of travel, the continuing reduction of travel times, and finally, mass media globalisation that has made different populations everywhere more aware of the outside world (Tisdell, 2004).

\footnotetext{
*Full Professor of Management, University of Milan-Bicocca (silvio.brondoni@ unimib.it)
} 
Another dimension of economic globalisation with implications for tourism is the growth of international alliances between various airlines and other parts of the tourism industry including the accommodation and hospitality sectors. Consequently, in the tourism sector, the concentration of capital is increasingly in the hands of a few major corporations; a trend that also drives tourism towards performance indicators and business practices demanded by the finance industry.

The concentration of power in the travel and tourism sectors continues to grow. Today, global firms are aware of the benefits of forming strategic alliances for location investments, destination marketing and product development. With networks and alliances, the management of tourism corporations will achieve greater economies of scale, marketing intelligence, quality control and cooperation (outside-in capabilities) (Brondoni, 2015; Riboldazzi, 2015).

The concentration of tourism implies specific development trends in different tourism sectors. The global power of airline alliances will continue to manifest with fewer large players and a number of niche operators, involving code-sharing, comarketing, joint purchasing and a network policy with smaller Asian airlines. In the accommodation sector, concentration entails the increasing consolidation of hotel groups, integrating products and services that were not originally part of the tourism product (e.g., insurance, car rental, luggage, etc.). Finally, a major trend involves the rapid growth of financial groups.

$\square$ China Life Insurance Co, the country's biggest insurer by market value, plans to boost its overseas investments to $15 \%$ of total assets in coming years from about $2 \%$ now. The company currently invests US\$7.6 billion in overseas assets. The main areas of its overseas investments will be property, logistics, hotels and retail. China Life has been working with about seven US private equity firms, and the United States and Europe will be the key markets for its overseas investments... Ping An Insurance Group Co of China, the second-largest insurer, is also aiming for a possible five-fold increase in overseas investments. China Life and Ping Ann's overseas ambitions mirror those of others, including Anyang Insurance Group and Osun International, which are spending billions on overseas acquisitions in a bid to reduce their dependence on the slowing domestic economy (Source: The Star Online http://www.thestar.com.my/business/business-news/2016/08/26/chinalife-to-raise-overseas-investments-to-15-pct-of-assets/).

$\square$ The Chief Operating Officer of China Business Network (CBN) visited Cyprus where he met with the Minister of Commerce, Energy and Tourism. Chinese Institutional investors are particularly keen on hotel, golf and other commercial projects (Source: http://www.chinainvests.net/).

$\square$ Dr Adam Wu, COO of the China Business Network (CBN) has been in Bermuda where he met with hoteliers and various business leaders, The CBN is a consortium of organizations specializing in business consultancy and marketing services for large numbers of Chinese and foreign authorities as well as other organizations. Direct foreign investment opportunities could open up if the Bermuda government 
loosens the 60-40 rule (where 60 per cent of a company must be Bermudian owned) (Source: http://www.china-invests.net/).

The Dorchester Group of the Sultan of Brunei in 2013 acquired the historic Hotel Eden in Rome. Also in Rome, the financial group Millennium \& Copthorne Singapore bought the Grand Hotel Baglioni and the Asian company Shangri-la acquired the Hotel Excelsior. Finally, the Qatar Investment Authority, Qatar's sovereign fund, recently acquired the luxurious Hotel Regina Baglioni in Rome and the Empire State Building, New York's symbolic skyscraper

A further problem associated with tourism concentration is that larger corporations commit to long-term relationships with specific destinations only when these involve large investments. The concentration generated by both horizontal and vertical integration is such that for medium-sized companies, profitability may be difficult to achieve, thus affecting local tourism development.

The globalisation of the tourism industry has some significant consequences. For instance, dramatically increasing competition by fostering entry into the industry, increasing the complexity of doing business in different countries and thus requiring knowledge focused on dynamic relationships. In this sense, managers of both private and public tourism organisations must interact with a complex global environment, using specific skills to respond to opportunities or address problems such as 'overcrowding of tourist attractions, overuse and destruction of natural resources, resident-host conflicts, loss of cultural heritage, increased crime and prostitution, inflation and escalating land costs, and a host of other political, sociocultural, economic and environmental problems that may be brought about or exacerbated by tourism development' (Moutinho, 2000; Heath, 2001).

In this sense, for example, China's economy "became much more open in the period 1980-2002, particularly in relation to its international trade in goods and services. This was partly a reflection of worldwide trends, and of specific policy measures adopted to liberalise its economic system and increase its participation in the international economy. During this period, China also experienced substantial growth in its involvement in international tourism. This is another feature of growing globalisation" (Tisdell, 2004).

China's tourism policy changed relatively slowly after 1978. However, by 1987, the Chinese Communist Party accepted that expansion of international inbound tourism was a key requirement for China's economic development. The then General Secretary of the CCP, Zhao Ziyang (1987), emphasised that the expansion of the industry would bring in foreign exchange for China which could be used to fund imports to fuel China's development. Furthermore, it was essential for foreign direct investors, or their representatives, to have access to China if they were going to invest (Tisdell, 2004). 
After 1987, China's inbound tourism grew more rapidly than its domestic tourism but by the mid-1990s, this appears to have been reversed (Moutinho, 2000).

A third phase in China's tourism policy has been to relax its restrictions on outbound travel. This began in 1990. Prior to 1990, nearly all outbound travel from China was for official or commercial purposes rather than for holidays or recreation. Increasingly, outbound travel for the latter purposes is being allowed. From 1990, holiday visits to some Southeast Asian countries were permitted. China's inbound tourism industry has grown spectacularly (Tisdell, 2004).

Over the years, travel and tourism have transformed into the world's largest economic sector, with enormous ramifications for both the physical and human spheres of industrialized and developing nations alike (Apostolopoulos \& Sönmez, 2000).

\section{Global Tourism Management. New Landscapes of Tourism Growth}

As tourism is essentially integrated with other sectors in the economy, tourism trends cannot be considered in isolation from key drivers that will shape the future world. Some trends operate at a global level and successful tourism management must recognise and deal with changes across a wide range of behavioural, technological and environmental factors (Dwyer et al., 2008). Since 1980, i.e., when globalisation began, global tourism management has faced numerous major shifts in the leisure and tourism environment, reflecting changing consumer behaviours, environmental changes and the explosive growth of information and communication technologies.

Globalisation has defined new landscapes of tourism growth and the emergence of a new tourist profile: traditional tourist motivations and behaviours have become outdated while tourism lifestyles have become more inconsistent and contradictory. It is no longer possible to predict the purchasing habits of tourists by simply labelling a group as 'upmarket' or 'price conscious'. In the current tourist market, various paradoxes in tourism behaviour are emerging side by side: greater risktaking and greater security, greater sameness and greater diversity. The same individuals may shop at a budget discount store, in a famous department store or dine at an exclusive upmarket restaurant (Heath, 2001).

The global landscapes of tourism growth also impose tourism management with a global approach, requiring organisations to manage change. In the mid-19th and early decades of the 20th century "transport developments were key-drivers of tourism change, major technological advances and the development of a larger tourism marketplace have become the global drivers of change in the tourism industry since the mid-nineties" (Heath, 2001).

In the last half-century, global tourism has registered a remarkable expansion. International arrivals have risen dramatically, but more importantly, the percentage of international arrivals as a percentage of the world population has also greatly increased (Table 1). 
2015 saw over one billion international tourist arrivals against around 25 million such arrivals in 1950. At the same time, the average relative international travel frequency of the world's population rose to over $11 \%$ in 2000 compared to less than $1 \%$ in 1950. Important to note is that, "Participation in international travel is geographically very uneven and accounted mainly for by residents of higher income nations" (Tisdell, 2004).

Table 1: International Tourist Arrivals and World Population (1950-2020)

\begin{tabular}{|l|l|l|l|}
\hline Year & $\begin{array}{l}\text { International Tourist } \\
\text { Arrivals } \\
\mathbf{( . 0 0 0} \text { persons })\end{array}$ & $\begin{array}{l}\text { World Population } \\
\mathbf{( . 0 0 0} \text { persons })\end{array}$ & $\begin{array}{l}\text { International Tourist } \\
\text { Arrivals as a \% of } \\
\text { World Population }\end{array}$ \\
\hline 1950 & 25.282 & 2.555 .360 & 0.99 \\
\hline 1960 & 69.320 & 3.020 .112 & 2.30 \\
\hline 1965 & 112.863 & 3.311 .621 & 3.41 \\
\hline 1970 & 165.787 & 3.675 .076 & 4.51 \\
\hline 1975 & 222.290 & 4.057 .284 & 5.48 \\
\hline 1980 & 284.282 & 4.428 .422 & 6.42 \\
\hline 1985 & 327.570 & 4.818 .994 & 6.80 \\
\hline 1990 & 481.134 & 5.250 .661 & 9.16 \\
\hline 1995 & 561.860 & 5.656 .213 & 9.93 \\
\hline 2000 & 700.789 & 6.052 .847 & 11.58 \\
\hline 2010 & 1.006 .400 & 6.812 .200 & 14.77 \\
\hline 2015 & 1.184 .000 & 7.349 .472 & 16.11 \\
\hline $2020^{(*)}$ & $1.350 .000^{*}$ & 7.758 .156 & $17.4 *-18.0 * *$ \\
\hline & $1.400 .000^{* *}$ & & \\
\hline
\end{tabular}

Sources: 1. The World Development Indicators (WDI) Online (for World Population), World Bank

2. The World Tourism Organisation (WTO) yearbooks, various years (for International Tourist Arrivals)

Note: The figures for 2020 are projections by the WTO**, World Bank and the Author*

$\square$ 2020. Evaluations of projections for International Tourist Arrivals. Among the world's top markets with double-digit growth in expenditure since 2004, China since July 2015 (executing the new economic course of President Xi Jinping) probably will not able to continue to lead global outbound travel, benefitting Asian destinations such as Japan and Thailand, as well as the United States and many European places. In addition, also the tourism expenditures of the Russian Federation and Brazil will decline considerably, reflecting their economic problems and the value depreciations.

International tourism has shown an astounding upward trend in the last sixty years in terms of international arrivals as a percentage of world population (Figure 1). Moreover, Figure 1 shows that this trend accelerated in the 1980s, i.e., from the beginning of globalisation, and that global tourism has accelerated in line with economic globalisation.

The growing trend of global tourism can be attributed to many factors, especially: higher incomes and better lifestyles of larger segments of the world population, greater disposable leisure and entertainment time for more and more people, lower real costs of global travel, reduced travel times, greater availability of international tourism locations segmented by different tourism behaviour, hotels and travel 
agencies responsive to the global tourism business, and finally, in the last 10-20 years, the growing interest of many global corporations (especially from the US and China) in investing large amounts of money in the tourism sector.

Figure 1: International Arrivals as a Percentage of World Population (1950-2020)

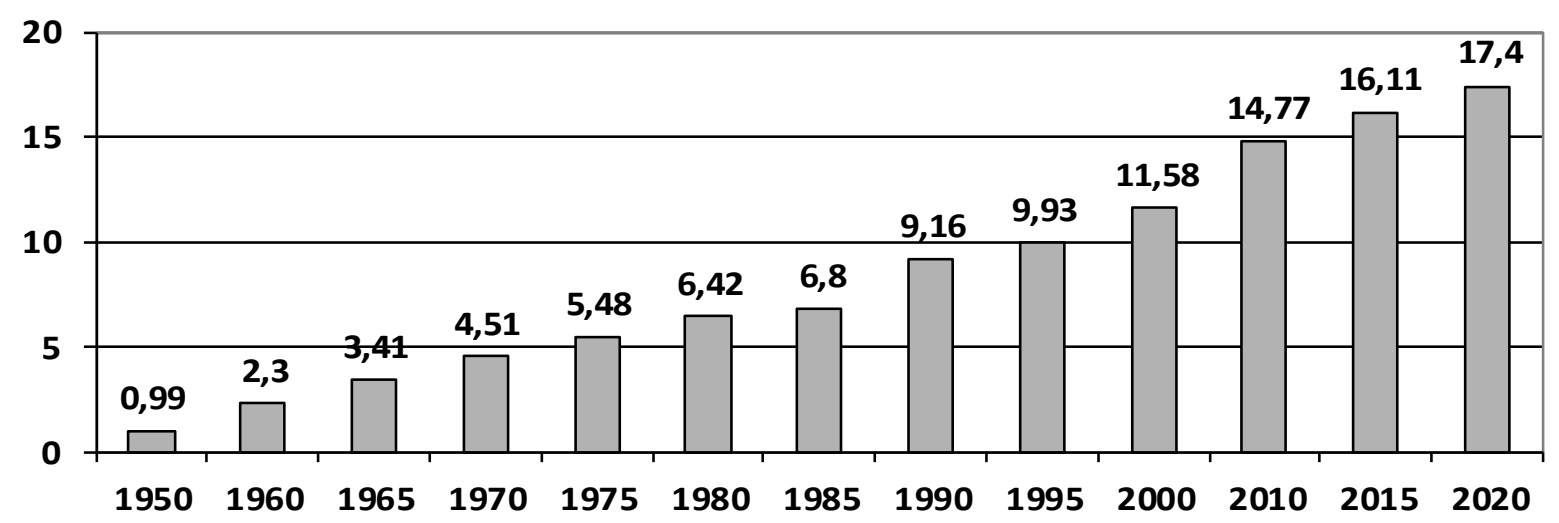

Source: The World Development Indicators (WDI) Online (for World Population), World Bank,

The World Tourism Organisation (WTO) yearbooks, various years (for International Tourist Arrivals) Note: The figures for 2020 are projections by the World Bank (for World Population) and the Author

Hyper-competition in the tourism industry is intensifying at many levels, including:

- Customers demanding improved quality at lower prices

- Rapid technological change enhanced through the use of IT

- The expansion of very aggressive global corporations willing to enter markets for a number of years with a loss leader product with a view to destroying the competition to harness the market in the long term

- Government barriers towards competition are progressively being removed throughout the world with some markets still holding back on the deregulation in the aviation sector (D'Aveni \& Gunther, 1994).

Hyper-competition and technological change for the tourism sector implies that the role of consumers will become increasingly important, especially in relation to service quality.

\section{Transfer Pricing in Global Tourism Management}

Over the past two decades, the global tourism industry has grown like no other. All countries (developed, non-developed and third world) have participated in the virulent growth of the global tourism business. In more recent years, this growth trend continues to manifest in countries with very positive socio-economic conditions (e.g., US, China, Germany, Switzerland, etc.), those with stagnant economic conditions (e.g., UK, Italy, Spain) or even recessive (e.g., Greece, Russia). In particular, 'rich' countries tend to participate in the global tourism industry with imposing 'outbound' tourism flows, while countries in negative 
phases of the economic cycle are especially active in receiving 'inbound' tourist flows.

The rapid development of global tourism and increasing global competition have caused profound changes in the corporate structure of large corporations, pushing them to adopt a very flexible network structure and absolutely geared towards performance and profit (at the group and individual local level).

In global tourism networks, tourism management faces two specific offer drivers and two demand drivers. Global demand drivers require management to develop different segments of global mass tourism. The offer drivers instead concern the corporate policies of transfer pricing and sustainability, often opposing forces but always correlated with short- and long-term profit.

Transfer pricing can be defined as the prices at which all goods and services are exchanged within a network of firms, i.e., companies with common interests. With transfer pricing, different companies participating in the same multinational group trade with each other (Deloitte Touche Tohmatsu, 2015), for example, when a USbased subsidiary sells/buys something to/from a French-based subsidiary. The transfer price is defined within (and not between) the companies of the same group.

In reality, corporations operating in global tourism are less concerned by the transfer price issue than the tax authorities of the countries in which they are based. Furthermore, the laws concerning transfer pricing are becoming more and more complex, as the tax policies of multinational firms are increasingly subject to regulatory authorities, the global and local media, and public opinion.

$\square$ In Ireland, tax on business income is 12.5 percent. In comparison, Italy next year will reduce tax on business income from 27.5 to 24 percent; still twice as much. Furthermore, in Ireland, tax on profits on intellectual property is only 6.25 percent. This is why corporations are very numerous and amount to around one thousand. In fact, nine of the ten largest global high-tech companies (from Google to Dropbox and Twitter) have their headquarters in Dublin as well as nine of the ten largest pharma corporations (from Johnson \& Johnson to GSK).

Global corporations can manipulate their prices and income to reduce taxes and other duties. In countries where tourism structures (hotels, resorts, etc.) are owned by foreign companies, transfer pricing can result in a substantial loss of public income.

In the global tourism industry, for example, if a service, of which the cost price is equal to $€ 900,000$, is billed at $€ 1,100,000$ by a French parent company to its American subsidiary and re-billed at \$1,200,000 by the American subsidiary to third party clients, the resulting profit will be taxed in France at a rate of $331 / 3 \%$ on $€ 200,000$ (i.e. a fiscal return for the French administration of $€ 200,000 \times 33 \quad 1 / 3 \%=$ $€ 66,666$ ), and in the United States at $35 \%$ on $\$ 100,000$ (i.e. a fiscal return for the US administration of \$100,000 x 35\% =\$35,000). The issue for governments with regard to transfer pricing is to call into question the allocation of the $€ / \$ 300,000$ margin between France and the United States. A reduction of $€ 100,000$ in the transfer price for 
example, would indeed lead to a reduction in French fiscal revenues of $€ 33,333$ and an increase in American fiscal revenues of \$35,000. On the other hand, the impact of such a correction for our group of companies in the example would be limited to the difference in the tax rate, which is relatively weak. In theory, the additional fraction in tax payable in the United States (\$35,000 in this example) would indeed be compensated by a reduction in the tax burden in France (of €33,333).

(Quenedey \& Colson, 2010).

Tourism income for a location is the amount of tourist expenditure that remains locally after taxes, profits and wages are paid outside the area and after imports are purchased; these subtracted amounts are known as leakage. Clearly, the amount of leakage increases in the presence of transfer pricing. Indeed, for most all-inclusive package tours, around $75-85 \%$ of traveller expenses are allocated to airlines, hotels and other global corporations that usually have their headquarters far from the local tourism destination.

Substantial high-income global tourism can significantly increase leakage, involving buying and selling relationships within a network of tourism firms. By contrast, some other selective segments (e.g., adventure tourism, ecological tourism, etc.) usually have a very low level of transfer pricing and these elective tourism segments obtain more value from local resources (Rauschelbach, 2002).

The different aspects that characterize transfer pricing become increasingly evident with the growth of global tourism and the increasing importance of global corporations in the international tourism business. In particular, the prominence of multinational enterprises in tourism and the need to achieve high growth and profit overall impose transfer pricing as a key global tourism management tool. Transfer pricing enables avoiding direct price competition with rival companies, obtaining profit margins through asymmetrical buy/sell relations determined by businesses outside the network and with respect to local economies.

\section{Sustainability in Global Tourism Management}

Transfer pricing is an increasingly common management policy in tourism corporation networks. The advantages in terms of profit are direct and become clearer with the progressive increase in company size.

However, transfer pricing causes significant harm to local economies. Tourism can develop strong synergies with the environment and society given that the development of tourist destinations is highly linked to their natural environment, the cultural characteristics and welfare of the local populations (Tisdell, 2013).

The negative effects of transfer pricing may be limited with corporate sustainability policies to establish a proper balance between corporate growth, the welfare of tourists and the needs of the natural and cultural environment, as well as between global competition and the preservation and development of local destinations (Brondoni, 2014; Salvioni \& Astori, 2013).

Global tourism generates notable public income and has become one of the most important worldwide industries, with the fastest development rate in national economies. For these reasons, the richest and poorest countries are focusing on sustainable tourism strategies, i.e., tourism tasked with durable growth, based on 
the planned construction of facilities and accommodation as well as oriented towards investments in the reconstruction of existing facilities, the progressive development of new tourism products (culture, business, leisure, etc.), improving of welfare of local populations and, finally, developing the potential of local territories.

$\square$ In global tourism, 'all-inclusive' vacation packages often reduce local income from tourists. When tourists remain for their entire stay at the same resort, which provides everything they need, nothing much is left for the local population from tourism. In the global tourism industry, 'all-inclusive' hotels generate large revenues, but their impact on local economies is smaller than other types of accommodation. The cruise ship industry provides another example of global 'enclave' tourism. On cruise ships, guests are often encouraged to stay on board and consequently opportunities to spend in local ports are closely managed and restricted.

Global firms must adopt a Triple Bottom Line (TBL) approach to sustainable development to ensure they integrate economic, social and environmental information into managerial decision-making to protect the tourism environment (natural, cultural and social) (Salvioni \& Astori, 2013; Perrini \& Vurro, 2010).

Global corporations aiming for the competitive and durable objective of sustainable tourism must enact management policies focused on the following principles:

- Balancing profitability of tourism investments with activities that have an impact on the local environment/society;

- Implementing sustainable programs with long-term plans for improving the resources and needs of the locations and their communities;

- Sharing the development tasks with all local parties concerned with sustainability (authorities, public operators and private companies).

To ensure effective and durable sustainability, global tourism corporations should pursue objectives aimed at:

- Preserving natural and cultural resources;

- Reducing to the minimum the use of resources in tourist locations;

- Limiting pollution and waste production;

- Studying the impact of tourism transport on the local environment;

- Ensuring the security and safety of tourists;

- Creating tourism without discrimination.

Global tourism is expected to continue to grow in the coming years in countries with high rates of economic growth, in those with stagnant economies and even those in decline (Tisdell, 2013). Tourism is also particularly relevant in terms of the numerous employment opportunities, especially among the young. These conditions drive the global tourism industry to integrate the protection of investments in resorts and activities with sustainable development programs, intended to protect the diversity and variety of cultures and regions. Sustainability programs, preserving and enhancing local differences enable global tourism corporations to offer innovative products (mass and selective, but always entailing high standardization) and high profit levels. 
Global tourism can be seen in terms of converging world tastes, product preferences and lifestyles whereby three main tourism segments ensue: mass global tourism and two speciality tourism segments (experience tourism and sensations tourism) that are very selective and based on customer oriented locations (e.g., Club Mediterranée). Global mass-market segments are instead characterised by high standardisation and market homogenisation (a trend towards similar customer preferences worldwide) with low travel and accommodation costs (i.e., Sharm el Sheikh) (Apostolopoulos \& Sönmez, 2000).

\section{Global Mass Tourism Management. Traditional Tourism, Experience Tourism and Sensations Tourism}

Globalisation, new tourism operators, the proliferation of new destinations and new technologies have changed the competitive environment and determined a new role of tourism in affluent societies and newcomer countries.

The end of the Second World War transformed the Mediterranean area (from the centre of world trade to the focal point of world tourism), encouraging the development of numerous tourist segments interested in the ancient world, the history of its peoples, cultures and religions, but also to enjoy the coastal and mountain scenery, and more generally, relaxing conditions.

Since the early 80s, globalization has profoundly changed tourism, which has become the single largest area of activity worldwide. The mobility of travellers and tourists has grown quickly over the years, on the one hand polarizing huge flows of mass tourism in Europe, on the other, marking the rapid growth of new destinations in Asia and the Pacific. In recent years, these new resorts have led to a significant decline in the share of the traditional Mediterranean mass market, which now represents around $40 \%$ of international tourist arrivals and $30 \%$ of total tourism revenues (World Tourism Organization, 2014; Montanari, 1995; Jenner \& Smith, 1993).

The traditional mass tourism model is characterized by a national producer's domination, with offers that are standardized, very poor and without variety. In this context, the oligopolistic dominance of a few companies emerged (primarily tour operators and airlines). Unchanging offers and prices constituted the key factors of firm competition, rather than the specific tourism content and the particularities of locations.

The progressive decline of large investments in traditional mass tourism can be attributed to numerous causes. First, the critical problems and instability related to terrorism, to migrants and political conflicts in many regions (e.g., North Africa, Turkey, Sun Belt). These factors have caused the stagnation of the traditional mass market in the Mediterranean (e.g., travellers from North Europe) and tend to be counteracted by the management and policies of global companies with different location choices (outside of the Mediterranean) that modify primary demand for local tourism. Indeed, the first terrorist acts devastated the Mediterranean area, but in more recent years have extended to other areas (e.g., Thailand), emphasizing on one hand, the close link between tourist investments and terrorism, and on the other, highlighting that global tourism has become a priority strategic objective, 
surpassing international finance (i.e., New York City and Washington, 11 September 2001) (Lambin, 2011).

In the last two years, some Mediterranean regions have obtained significant benefits from the contraction of big tourist investments and mark contrasting trends, as in the case of Sardinia and other Italian and Spanish sub-regions. However, these phenomena appear to be primarily related to the movement of tourism flows (perhaps due the perception as safer locations), rather than new tendencies of substantial investments in mass tourism based on specific destinations (traditional mass tourism).

$\square$ Since 2014, arrivals and presences in Sardinia have soared and nearly 20 percent of inflows has been recouped, with a steady increase in foreign travellers and the recovery of the national market (Source: http://www.meteoweb.eu/2016/08/turismo-in-sardegna)

Another factor of attracting fewer investments in traditional mass tourism is the poor rate of renewal of the Mediterranean tourism offer (Apostolopoulos \& Sönmez, 2000). The limited innovation in tourism products in the Mediterranean has largely been caused by the fragmentation of national tourism policies, which are uncoordinated, dispersed across multiple organizations, slow in implementation and development, but mainly never aimed at encouraging travellers and tourists to return ('hit and run' tourism). In general, the slow innovation in traditional mass tourism products has also been considerably damaged by the rapid return on investments that today characterize global mass tourism products (time-based competition) (Brondoni, 2002). Furthermore, the corporate policies of global tourism companies focus on competitive market-driven management policies (Arrigo, 2009; Gnecchi, 2009; Salvioni, 2008; Brondoni, 2008; Day, 2001) and can thus only adapt to the choices of national tourism operators. Such policies, usually without planning and programming bases, increasingly lead global tourism companies to disregard the Mediterranean as a primary investment area.

Furthermore, the strong seasonal nature of tourism (over $40 \%$ of business is concentrated between June and September) is a serious cause of the decline of traditional mass tourism. Seasonality explains, for example, the international investment choices in organized tourist resorts (locations and infrastructure) in Egypt, Tunisia, Turkey, etc., whose geographic locations enable extending the tourist season. These locations however are primary targets of dramatic terrorist acts, aimed at striking at the local tourism industry and hence international investments. In addition, in this case, management policies tend to take the form of new mass tourism proposals, directing new investments towards safer destinations and reducing investments in the regions under terrorist attacks. These new destinations derive from management policies developed by corporations according to a global competition approach, setting out to create and develop new global tourism segments (ecotourism, cultural tourism, extreme sports tourism, etc.). Corporate global tourism policies therefore focus first on mass tourism products, channelling massive tourist flows towards integrated tourism destinations (consisting of locations and heavy infrastructures such as airports, ports, etc.). At the other extreme, creating a highly characteristic and volatile offer, abandoning the traditional residential tourism model (Figure 2) to meet the new expectations 
(driven by global mass media) of tourists and travellers based on specialty tourism drivers, particularly experience tourism and sensation tourism. Global tourism changes the nature of the production and consumption of tourism products, providing the tourist experience with innovative new products (Brondoni, 2012).

Figure 2: Private Accommodation Offered by Airbnb (Italy, 2009-2015)

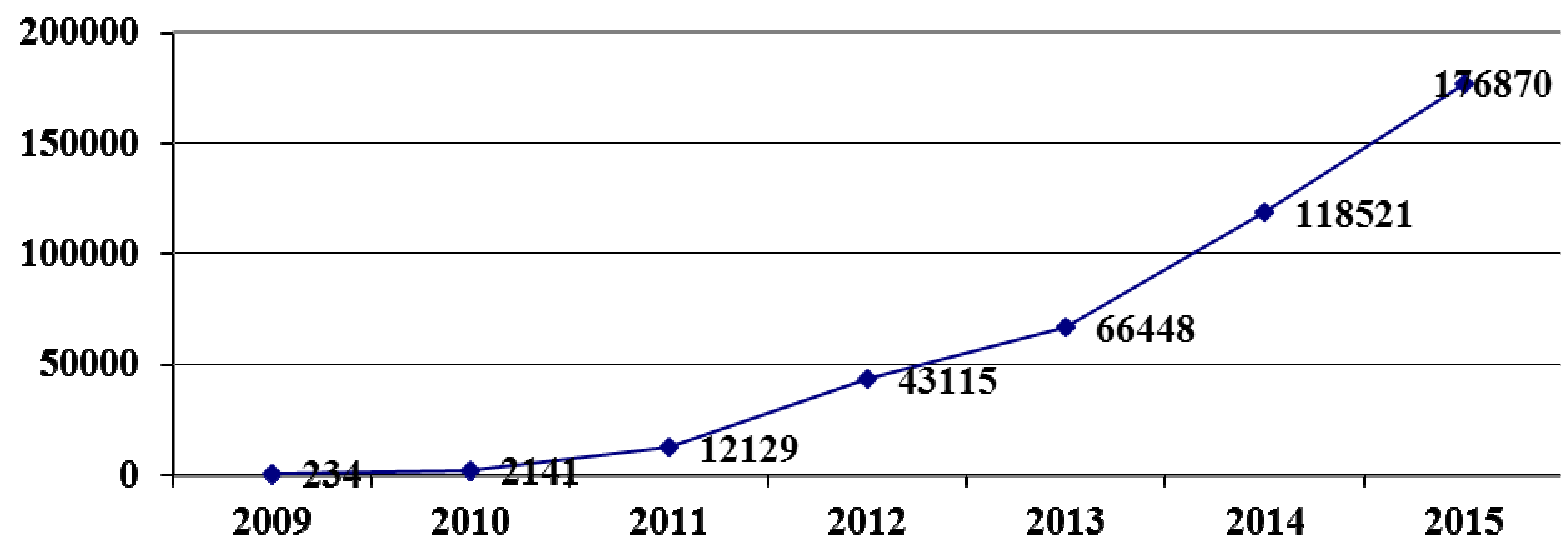

Differentiation of vacation types, the competitive proliferation of new destinations, the creation of demand bubbles in traveller preferences and the growth of softer forms of tourism (B\&B, rent-a-house, sharing accommodation, etc.) overall constitute new dimensions that stress the quality of the tourist experience. In this sense, the environment will acquire a premium image, generating economic results for durable tourism, while the sites and destinations will gain the attention of travellers (Bellini, 2004).

Until a few years ago, apartments were only rented for long vacations. The minimum period was one week. Now, however, many tourists and travellers prefer a 'lived-in' home even for a weekend, because it is not about renting the accommodation, but choosing and acquiring an experience. Thus, in global markets this imposes the primacy of a tourism experience with mass sharing, superseding the pre-packaged paths of mass tourism to affirm contact with residents and with the real life of the location.

Experience tourism is a targeted form of mass tourism based on market-driven management, international demand bubbles, price competitiveness, destination image and high product quality particularly in relation to customer sensitivity and perceptions (Capriello et al., 2013; Volo, 2009). For experience tourism, tour operators, hotel comfort and service standards are not paramount to a destination's attractiveness, which instead is the case for traditional mass tourism (Heath, 2000; Brackenbury, 1996).

Tourists want to be involved, to learn experiences, interact with the community and learn about and appreciate the destination on more than a superficial level. People go on holiday to learn something. For an increasing number of tourists, a holiday has become an investment instead of a form of consumption. 
In health tourism, for example, tourists are interested in self-improvement as part of the tourism experience with a specific emphasis on developing wellbeing skills.

Other examples of mass experience products are based on planned activity programs (such as sports and hobbies, cruise tourism or cultural and heritage tourism) where people are motivated to pay for sharing high-level experiences. Travellers seeking experience tourism are usually aware of what package tours can offer and look for tailored programs or advanced 'modules'. The experience tourist emphasises 'value for money' pricing, often not necessarily opposed to the cheapest package price.

Experience tourism communities are interest-based and self-publish on blogs, trip diaries, videos, creating and sharing images, clips, opinions, chat rooms, groups, blogs and podcasts. The smartest destinations offer videos, photos, maps, trip planners, travel guides, transport, attractions, private accommodation, $\mathrm{B} \& \mathrm{~B}$, hotel and other information.

In experience tourism, communities advance from a simple online travel booking to advanced content and in so doing generate development trends, analysing and sharing destinations and operators for specific interest groups.

Experience tourists seek more individualised experiences, often characterised as special-interest travel. Such travellers are more interested in enriching their lives with experiences rather than hands-off entertainment. They pursue interactive, highly involved, quality travel experiences, focusing on in-depth coverage of the special interest topic or destination at hand (McIntosh et al., 2009; Heath, 2000; Brackenbury, 1996).

Today, the great challenge for the global tourism industry is to be continuously competitive and innovative in a worldwide landscape, using marketing strengths to define trends and priorities, pushing tourists towards types of tourism (and destinations) that global corporations can offer.

In particular, new and targeted mass-market tourism consists of 'new tourists' seeking specific forms of sensations tourism. Specialty sensations tourism markets currently cater mainly for the following interests: adventure tourism, nature-based tourism, nomad tourism, religious tourism, fitness and wellness tourism, rural tourism, urban tourism, special event tourism, deaths and disasters tourism. The 'sensations tourist' can be described as "an individual who will shun the homogenised, mass market tourism products and destinations in favour of a more adventurous, active and individualised approach to holiday taking" (Poon, 1993).

$\square$ Virgin Hotels is a US chain founded in 2010 in Miami by Richard Branson in a project where the target customers are women travelling for work. These customers are sophisticated guests who tend to prolong the trip, staying even over the weekend and looking for comfort and safety. The rooms were designed by the Rockwell Group Europe and are divided into two spaces separated by a door with a key, to avoid direct contact with staff. With light everywhere, especially in the first part of the room, where women usually dress and apply makeup. In the hotel in Chicago, the rate is $\$ 209$ per night.

The sensations tourist's priority is a specific tourism task, whereas the destinations, hotels and so forth, are less important. The personal profile of this type 
of tourist is defined as "an older age group, well-travelled, educated, discerning, demanding, environmentally aware and prepared to pay a premium for high quality products and services" (Heath, 2001).

Global sensations tourism products are associated with the increased sophistication of this type of global tourist, more conscious of value for money than simply price, and more critical of standards of product design, efficiency and safety. In other words, quality remains a key factor in sensations tourism product development and the global sensation tourist will expect price convenience, but first of all specific and high product characteristics oriented to tailored customer satisfaction.

In extreme synthesis, experience and sensations tourism have a common and distinctive trait that differentiates these from global mass tourism. The latter presupposes the choice of a tourist destination, which is therefore the primary element for planning and programming the investments of corporations and private and public organizations involved in the tourism business in a certain location. By contrast, the drivers of experience and sensations tourism are respectively and precisely the experiences and sensations experienced and/or expected by tourists and travellers in relation to specific themes, where the locations, transport and hospitality facilities are assessed (and judgments shared) on the degree of satisfaction obtained and in practice determining the choice of location.

\section{Global Tourism Management. Emerging Trends}

In conclusion, the various globalisation trends and developments outlined indicate that in the future, mass global tourism will be less standardised and packaged in an increasingly flexible way. At the other extreme, elective global tourism will be less segmented and more targeted and customised. Targeted tourism products will be primarily orientated towards health, education and specialty entertainment.

Technology and telecommunications will dominate in the future tourism industry. Virtual reality in tourism could significantly replace the physical travel experience (Holmes, 2001). Travelers could be virtually transported to the sensations, sounds and sights of a location, with the possibility of experiencing a destination without visiting it. With virtual tourism, the tourist could visit a destination safely, without effort and at a low cost. However, the tourism locations would lose the positive effects of income, job creation and regional development.

Globalisation and the socio-economic interests of the locations force mass tourism stakeholders to plan, program and invest globally.

By contrast, experience and sensations mass tourism will focus on the internet, ecommunities, value for money, speed, efficiency and safety. The polarisation of tourism behaviours will be more and more evident (e.g., comfort-based versus theme-orientated). In the past, the focus was predominantly on travel, hospitality and travel agency characteristics. Conversely, now tourism managers must consider and include other key elements in tourism and destination programs, such as country image and attraction, the sharing economy, events, local transportation, service standards, and last but not least, safety and security ensured by carriers and destinations. 
Positioning, branding and destination image will be increasingly important in global tourism marketing and travellers will place increasing importance on sustainable tourism development programs.

Finally, the tourism industry will face greater consumer socio-environmental consciousness that imposes sustainable tourism development and ethical business practices.

\section{Bibliography}

Adejuwon, F. (1996). Globalisation of Tourism and its Effects on Africa with Special Regard to Nigeria, in Keller, P. (ed.), Globalisation and Tourism, AIEST, St. Gallen.

Apostolopoulos, Y., \& Sönmez. S. (2000). New Directions in Mediterranean Tourism: Restructuring and Cooperative Marketing in the Era of Globalization, Thunderbird International Business Review, 42, (4), 381-392.

Arrigo, E. (2012). Alliances, Open Innovation and Outside-in Management, Symphonya. Emerging Issues in Management (symphonya.unimib.it), (2), 53-65.

http://dx.doi.org/10.4468/2012.2.05arrigo

Arrigo, E. (2009). Market-Driven Management, Global Competition and Corporate Responsibility, Symphonya. Emerging Issues in Management (symphonya.unimib.it), (1), 54-70.

http://dx.doi.org/10.4468/2009.1.06arrigo

Bellini, N. (2004). Territorial Governance and Area Image, Symphonya. Emerging Issues in Management (symphonya.unimib.it), (1), 14-26.

http://dx.doi.org/10.4468/2004.1.03bellini

Brackenbury, M. (1996,). New Opportunities for the Mediterranean, Inter-Ministerial Tourism Conference "Marketing the Mediterranean as a Region", November 7-9, Sliema, Malta.

Brondoni, S. M. (2015). Global Networks, Outside-In Capabilities and Smart Innovation, Symphonya. Emerging Issues in Management (symphonya.unimib.it), (1), 6 - 21.

http://dx.doi.org/10.4468/2015.1.02brondoni

Brondoni, S. M. (2014). Global Capitalism and Sustainable Growth. From Global Products to Network Globalisation, Symphonya. Emerging Issues in Management (symphonya.unimib.it), (1), $10-31$.

http://dx.doi.org/10.4468/2014.1.02brondoni

Brondoni, S. M. (2013). Innovation and Imitation for Global Competitive Strategies. The Corporation Development Models of US, Japan, Korea, and Taiwan, Symphonya. Emerging Issues in Management (symphonya.unimib.it), (1), 12 - 27.

http://dx.doi.org/10.4468/2013.1.02brondoni

Brondoni, S. M. (2012). Innovation and Imitation: Corporate Strategies for Global Competition, Symphonya. Emerging Issues in Management (symphonya.unimib.it), (1), 10-24.

http://dx.doi.org/10.4468/2012.1.02brondoni

Brondoni, S. M. (2008). Market-Driven Management, Competitive Space and Global Networks, Symphonya. Emerging Issues in Management (symphonya.unimib.it), (1), 14-27.

http://dx.doi.org/10.4468/2008.1.02brondoni

Bulhalis, D. \& Cooper, C. (1998). Competition or Co-Operation? Small and Medium Sized Tourism Enterprises at the Destination, in Embracing and Managing Change in Tourism: International Case Studies, Laws, E., Faulkner, B. \& Moscardo, G. (eds.), 324-346, Routledge, London.

Capriello, A. , Mason, P. R., Davis, B. \& Crotts, J. C. (2013). Farm Tourism Experiences in Travel Reviews: A Cross-Comparison of Three Alternative Methods for Data Analysis, Journal of Business Research, (6) 66, 778-785.

http://dx.doi.org/10.1016/j.jbusres.2011.09.018 
Clift, S., Page, S. (2015). Health and the International Tourist, Routledge, London

Coles T, Hall C.M. (eds). 2008. Tourism and International Business, Routledge, London

Cook, R., Yale, L., \& Marqua, J. (1999). Tourism: The Business of Travel, Prentice-Hall, Upper Sadle River

Cooper, C., Fletcher, J., Fyall, J., Gilbert, D. \& Wanhill, S. (1999). Tourism Principles and Practices (4nd ed.) Prentice-Hall, Upper Sadle River.

Cooper. C., \& Hall, CM. (2013). Contemporary Tourism: an International Approach, 2nd ed. Goodfellow, Oxford

D’Aveni, R.A., Gunther, R. (1994). Hypercompetition: Managing the Dynamics of Strategic Manoeuvring. The Free Press, New York.

Day, G. (2001). Market Driven Winners, Symphonya. Emerging Issues in Management (symphonya.unimib.it), (2), 12-22.

http://dx.doi.org/10.4468/2001.2.02day

Deloitte Touche Tohmatsu Ltd (2015), Global Transfer Pricing Country Guide, Deloitte, London,

Dwyer, L., Edwards, D., Mistilis, N., Scott, N., \& Cooper, C. (2008). Megatrends Underpinning Tourism to 2020: Analysis of Key Drivers for Change, CRC for Sustainable Tourism, Pty Ltd, Sydney.

Gnecchi, F. (2009). Market-Driven Management, Market Space and Value Proposition, Symphonya. Emerging Issues in Management (symphonya.unimib.it), (2), 33-45.

http://dx.doi.org/10.4468/2009.2.04gnecchi

Gössling, S., \& Hall, C. (eds). (2006). Tourism and Global Environmental Change, Routledge, London

Grant, R. M., \& Baden-Fuller, C. (2004). A Knowledge Accessing Theory of Strategic Alliances, Journal of Management Studies, (41), 1, 61-84.

http://dx.doi.org/10.1111/j.1467-6486.2004.00421.x

Grant, R. M. (2000). Shifts in the World Economy: The Driver of Knowledge Management, in C. Despres, \& D. Chauvel (eds.), Knowledge Horizons: The Present and the Promise of Knowledge Management, Butterworth-Heinemann, Oxford

Hall, C. M., Scott, D., \& Gössling, S. (2013). The Primacy of Climate Change for Sustainable International Tourism. Sustainable Development, 21(2), 112-121.

http://dx.doi.org/10.1002/sd.1562

Heath, E. (2001). Globalisation of the Tourism Industry: Future Trends and Challenges for South Africa, SAJEMS NS, (4) 3, 542-569.

Heath, E. (2000). Key Trends in Destination Marketing: Lessons from Global 'Best Practice' Destinations, in: Ruddy, J. \& Flanagan, S. (eds.), Tourism Destinations: Gaining the Competitive Edge, Tourism Research Centre, Dublin Institute of Technology, Dublin.

Holmes, D., (ed.) (2001). Virtual Globalization: Virtual Spaces/Tourist Spaces, Routledge, London.

Hjalager, A. M. (1997). Innovation Patterns in Sustainable Tourism: An Analytical Typology. Tourism Management, 18(1), 35-41.

http://dx.doi.org/10.1016/S0261-5177(96)00096-9

Jenner, P., \& Smith, C. (1993). Tourism in the Mediterranean. The Economist Intelligence Unit, London

King, B. \& McVey, M. (2003). China Outbound, Travel and Tourism Analyst, 1, 1-32.

Keller, P. (1996) Globalisation of Tourism, AIEST, St Gallen.

Kyungmi Kim, Muzaffer Uysal, M. Joseph Sirgy (2013). How does Tourism in a Community Impact the Quality of Life of Community Residents? Tourism Management, 36, 527-540 http://dx.doi.org/10.1016/j.tourman.2012.09.005

Lafferty, G., \& van Fossen, A. (2001). Integrating the Tourism Industry. Problems and Strategies. Tourism Management, 22 ,(1), 11-19

http://dx.doi.org/10.1016/S0261-5177(00)00021-2 
Lambin, J.J. (2002). Strategic Marketing Revisited after September 11, Symphonya. Emerging Issues in Management (symphonya.unimib.it), (1), 7-27.

http://dx.doi.org/10.4468/2002.1.02lambin

Mazilu, M. \& Marinescu,. R. . (2008). Excellency Or Chaotic Globalization In Tourism?. Annals of the University of Oradea, Economic Science Series, 17(2), 699-702.

McIntosh, R. W., Goeldner, C. R., Ritchie, J. R. B. (2009). Tourism: Principles, Practices and Philosophies (11th ed.), John Wiley \& Sons, New York.

Montanari, A. (1995). The Mediterranean Region: Europe's Summer Leisure Space, in. Montanari A. \& Williams A.M. (eds.), European Tourism: Regions, Spaces, and Restructuring, Wiley, Chichester.

Moutinho, L. (2000). Strategic Management in Tourism, CABI Publishing, New York.

Munar, A. M. \& Jacobsen, J. K. S. (2014). Motivations for Sharing Tourism Experiences through Social Media, Tourism Management (43), 46-54.

http://dx.doi.org/10.1016/j.tourman.2014.01.012

Musso, F. \& Risso, M. (2006). CSR within Large Retailers International Supply Chains, Symphonya. Emerging Issues in Management (symphonya.unimib.it), (1), 79-92.

http://dx.doi.org/10.4468/2006.1.06musso.risso

Page Stephen J. (2015). Tourism Management, $5^{\text {th }}$ ed., Routledge, London.

Page, S., Brunt, P., Busby, G. \& Connell, J. (2001). Tourism: A Modern Synthesis, Thomson Learning, London

Perrini, F. \& Vurro, C. (2010). Corporate Sustainability, Intangible Assets Accumulation and Competitive Advantage Constraints, Symphonya. Emerging Issues in Management (symphonya.unimib.it), (2), 25-38.

http://dx.doi.org/10.4468/2010.2.03perrini.vurro

Poon, A. (1993). Tourism, Technology and Competitive Strategies, International, Wallingford.

Quenedey A. \& Colson A. (2010). Transfer Pricing of Intangibles, Bird \& Bird, Global, November 22.

Rauschelbach B., Schäfer A., Steck B. (eds.) (2002). Cooperating for Sustainable Tourism, Kasparek Verlag, Heidelberg.

Riboldazzi, S. (2015). R\&D and Product Engeneering in Global Pharmaceutical Companies, Symphonya. Emerging Issues in Management (symphonya.unimib.it), (2), 57 - 74.

http://dx.doi.org/10.4468/2015.2.05riboldazzi

Salvioni, D. M. \& Astori, R. (2013). Sustainable Development and Global Responsibility in Corporate Governance, Symphonya. Emerging Issues in Management (symphonya.unimib.it), (1), 28-52.

http://dx.doi.org/10.4468/2013.1.03salvioni.astori

Salvioni, D. M. (2010). Intangible Assets and Internal Controls in Global Companies, Symphonya. Emerging Issues in Management (symphonya.unimib.it), n. 2, 39-51.

http://dx.doi.org/10.4468/2010.2.4salvioni

Salvioni, D. M. (2008). Market-Driven Management and Corporate Governance, Symphonya. Emerging Issues in Management (symphonya.unimib.it), (2), 13-27.

http://dx.doi.org/10.4468/2008.2.02salvioni

Tisdell, C.A. (2013). Competition, Diversity and Economic Performance. Edward Elgar, Cheltenham.

Tisdell, C.A. (2013). Economic Self-Reliance and China's Development: Changing Perspectives, International Journal of Development Issues, 12, 3, 239-252.

http://dx.doi.org/10.1108/IJDI-03-2013-0029

Tisdell, C. A. \& Clevo, W. (2012). Nature-Based Tourism And Conservation: New Economic Insights And Case Studies, Edward Elgar Publishing, Cheltenham.

Tisdell, C. A. (2004). Tourism Development as a Dimension of Globalisation: Experiences and Policies of China and Australia, The University Of Queensland, May, Working Paper No. 31 
Vanhove, N. (1996). Globalisation of Tourism Demand: The Underlying Factors and the Impact on Marketing Strategy, in Keller, P. (ed.), Globalisation and Tourism, St. Gallen, AIEST.

Vellas, F.A. \& Becherel, L. (1999). The International Marketing of Travel and Tourism: A Strategic Approach, MacMillan, London.

Volo, S. (2009). Conceptualizing experience: A Tourist Based Approach, Journal of Hospitality Marketing \& Management, 18(2-3), 111-126.

http://dx.doi.org/10.1080/19368620802590134

Wen, J.J., \& Tisdell, C.A. (2001). Tourism and China's Development: Policies, Regional Economic Growth, and Ecotourism, World Scientific, Singapore.

Werther, H., \& Klein, S. (1999). Information Technology and Tourism: A Challenging Relationship, Springer-Verlag, New York

Witt, S. S., Brooke M. Z. \& Buckely P. J. (2013). The Management of International Tourism, Routledge, London 